\title{
Calathea matudae and C. sousandradeana, New Species of Marantaceae from Mexico and Northern Central America
}

\author{
Helen Kennedy \\ UCR Herbarium, Department of Botany and Plant Science, University of California, Riverside, \\ Riverside, California 92521, U.S.A. ganders@interchange.ubc.ca \\ Fred R. Ganders \\ Department of Botany, University of British Columbia, Vancouver, British Columbia V6T 1Z4, \\ Canada.ganders@interchange.ubc.ca
}

Abstract. Two species of Marantaceae, Calathea matudae H. Kenn. \& Ganders from Chiapas, Mexico, to Honduras, and C. sousandradeana H. Kenn. \& Ganders from Veracruz and Oaxaca, Mexico, are described as new for inclusion in Flora Mesoamericana. Calathea matudae differs from C. atropurpurea Matuda in lacking reduced basal inflorescences, the bract acumen that is shorter and acute at the tip, the bracts that consistently dry brown, and the cross veins between the lateral veins of the leaves that are farther apart (15 to 20 per $5 \mathrm{~mm}$ vs. 23 to 30 per 5 $\mathrm{mm}$ in C. atropurpurea). Calathea sousandradeana differs from $C$. matudae and $C$. atropurpurea by the smaller, glabrous bracts with obtuse to rounded margins in the upper ones. A key is provided to the Mexican species in Calathea sect. Breviscapus Benth.

Resumen. Dos especies de Marantaceae, Calathea matudae H. Kenn. \& Ganders de Chiapas en México hasta Honduras, y C. sousandradeana H. Kenn. \& Ganders de Veracruz y Oaxaca en México, se describen como nuevas para su inclusión en la Flora Mesoamericana. Calathea matudae es diferente de $C$. atropurpurea Matuda en no tener inflorescencias basales reducidas, el acumen de la bráctea mas corto, agudo en el ápice, las brácteas secan consistentemente de color café, y los nervios transversales entre los nervios laterales de la hoja son más separados (15 hasta 20 por cada $5 \mathrm{~mm}$ vs. 23 hasta 30 por cada 5 $\mathrm{mm}$ en $C$. atropurpurea). Calathea sousandradeana es diferente de $C$. matuda y $C$. atropurpurea en las brácteas más pequeñas y glabras con el margen apical obtuso hasta redondo en los brácteas superiores. Se proporciona una clave para las especies mexicanas de Calathea sect. Breviscapus Benth.

Key words: Calathea, Chiapas, Honduras, IUCN Red List, Marantaceae, Mexico, Oaxaca, Veracruz.

As part of the Flora Mesoamericana project, the Mexican species of Calathea G. Mey. (Marantaceae) were examined to resolve the taxonomic problem concerning those taxa with basal leaves, spirally arranged green bracts, and yellow flowers (in Calathea sect. Breviscapus Benth.).

Two species in Calathea sect. Breviscapus were described by Matuda from Mexico. In 1950, he described $C$. ovandensis Matuda from Chiapas. In a later paper (Matuda, 1956), he described a second species, C. atropurpurea Matuda, from Estado de México. Calathea coccinea Standl. \& Steyerm. (Standley \& Steyermark, 1944) from southern Mexico to Guatemala and, more recently, C. misantlensis Lascur. (Lascurain, 1996) from Veracruz are likewise in Calathea sect. Breviscapus, but are readily distinguished by their red flowers, red bracts, and bract morphology.

Collections of the green-bracted plants from the Mexican states of Oaxaca, Veracruz, and Chiapas, Guatemala, and Honduras have been variously identified as either Calathea ovandensis, C. atropurpurea, or affined species. These plants appear quite similar in overall morphology, especially as dried specimens. They all have ovoid to ellipsoid, relatively small (2.5-6.5 cm) inflorescences, spiral green bracts, and claviculate bracteoles. Additionally, these taxa are all deciduous, often first producing an inflorescence on a leafless shoot, and the leaves are relatively thin textured and pubescent throughout on the adaxial surface. This last character is not only quite distinctive of this collected group, but is quite rare within Calathea overall (though it is shared with C. coccinea and C. misantlensis). Flower color is variously noted as yellow or cream-white, or the corollas may be tinged or streaked with purple or lilac, or entirely purple.

When all the material extending from Sinaloa, Mexico, to Honduras was laid out in a geographical sequence, a distinctive pattern of variation emerged: three different taxa were apparent. Mexican populations from Sinaloa to Guerrero have generally larger 
inflorescences with attenuate, apically recurved, pubescent bracts. They often have one to five (to 10) reduced basal inflorescences in the axils of cataphylls (see Fig. 1D). These inflorescences are irregularly ovoid, 1-1.6 cm long, with three to five unequal bracts, on peduncles $2-5 \mathrm{~cm}$ long, while the terminal inflorescences are ellipsoid, 2.5-4.5 $\times 1$ $1.5(-2.5) \mathrm{cm}$, with (10)15 to 25 bracts, on peduncles 20-40 cm long (McVaugh, 1989). These northernmost populations are consistent with Matuda's type of Calathea atropurpurea. Populations from Oaxaca and Veracruz constitute a distinct species, contrasting sharply with their smaller inflorescences with obtuse to rounded, nonrecurved, glabrous bracts. This species, C. sousandradeana H. Kenn. \& Ganders, described herein, was included under the name $C$. ovandensis, with a drawing of the inflorescence, by Lascurain (1995: 15-18, fig. 1j) in the Flora de Veracruz. The specimens from Chiapas south to Honduras more closely resemble $C$. atropurpurea, having generally larger inflorescences with recurved acuminate, tomentose bracts, and they were frequently annotated as such, by myself and others, especially for Honduran material. However, this material constitutes a distinct species, C. matudae H. Kenn. \& Ganders, described herein, that is distinguished by the absence of reduced, basal inflorescences and by the acumen that is always sharply pointed (acute) at the very tip, whereas the acumen is elongated and its very tip blunt to rounded in most, if not all, of the upper bracts in $C$. atropurpurea (compare Fig. $1 \mathrm{~F}$ and 1E). Another character distinguishing $C$. matudae from $C$. atropurpurea is that the cross veins between the lateral veins of the leaves are farther apart (15 to 20 per $5 \mathrm{~mm}$ vs. 23 to 30 per $5 \mathrm{~mm}$ in $C$. atropurpurea), when measured in the middle part of each half of the leaf.

In his treatment of the Marantaceae of Chiapas, Matuda (1950: 333) described the new species Calathea ovandensis. After examining the type, Matuda 1568 (holotype, MEXU; isotypes, F, MICH not seen), it was clear that Matuda had typified $C$. ovandensis on a collection of $C$. coccinea. The additional material he cites, Matuda 5993 (F, LL, MEXU), is also $C$. coccinea. Thus, $C$. ovandensis can be considered as synonymous with $C$. coccinea. However, in reading the description for $C$. ovanden$s i s$, it is clear that Matuda also included material of a second taxon (C. matudae, described herein). The drawing (Matuda, 1950: 332) is clearly not $C$. coccinea, but another, presumably Chiapan taxon, as are the measurements given for the inflorescence. It is understandable that when comparing material with this published illustration, botanists would adopt the name as being the best fit to a described species of the region. The compact inflorescence with relatively wide, closely overlapping bracts, as illustrated, could hardly be mistaken for that of $C$. coccinea. However, the description of bract length, bract width, and flower color clearly fit $C$. coccinea. Matuda (1950: 335) noted that Standley and Steyermark said that at flowering, $C$. coccinea "no se han desarrollado las hojas aún...," but in his species "...están extendidas las hojas perfectamente...." Although variable, the presence of leaves accompanying the inflorescence is very common in the case of C. matudae, but is also seen in Chiapan specimens of C. coccinea (Breedlove 25483, DS, MEXU, MO; Utley \& Utley 6810, MO). The distribution and characteristics of the proposed new species $C$. matudae strongly suggest that it is, in fact, this second element included in Matuda's description of $C$. ovandensis. Matuda himself annotated a specimen of it, Miranda 5397 (MEXU), as C. ovandensis.

\section{Key to the Species of Calathea sect. Breviscapus in Mexico}

la. Corolla red, bracts red (or occasionally green or yellow in $C$. misantlensis).

2a. Inflorescence subcylindric, $1.3-2.3 \mathrm{~cm}$ wide, 2.2 $5(-5.7) \times$ longer than wide, borne on leafless shoots ....................... C. coccinea

2b. Inflorescence ovoid to broadly ovoid, 2.5-6.5 $\mathrm{cm}$ wide, $<2 \times$ longer than wide, borne on leafy shoots $\ldots \ldots \ldots \ldots \ldots \ldots$. . misantlensis

1b. Corolla yellow, cream-white, or purple, bracts green or green tinged with purple.

3a. Bracts glabrous, apex obtuse to rounded in upper bracts; bract apex and margin erect, not recurved; Oaxaca and Veracruz ....... $\ldots \ldots \ldots \ldots \ldots \ldots \ldots \ldots$ C. sousandradeana

3 b. Bracts tomentose, apex acuminate in upper bracts, apex or apex and margin usually recurved; Sinaloa south to Guerrero or Chiapas.

4a. Acumen of upper bracts elongated, blunted or rounded at very tip; reduced basal inflorescences usually present; 23 to 30 cross veins per $5 \mathrm{~mm}$ between the lateral veins in the middle of each half of the leaves; Sinaloa south to Guerrero ............... C. atropurpurea

4b. Acumen of upper bracts not elongated, sharply pointed, acute at very tip; reduced basal inflorescences absent; 15 to 20 cross veins per $5 \mathrm{~mm}$ between the lateral veins in the middle of each half of the leaves; Chiapas .... C. matudae

1. Calathea matudae H. Kenn. \& Ganders, sp. nov. TYPE: Mexico. Chiapas: Mpio. Ocozocoautla de Espinosa, $18 \mathrm{~km}$ from Ocozocoautla on rd. to Malpaso, ca. 3200 ft., I Aug. 1972, H. Kennedy \& D. E. Breedlove 1414 (holotype, MEXU; 


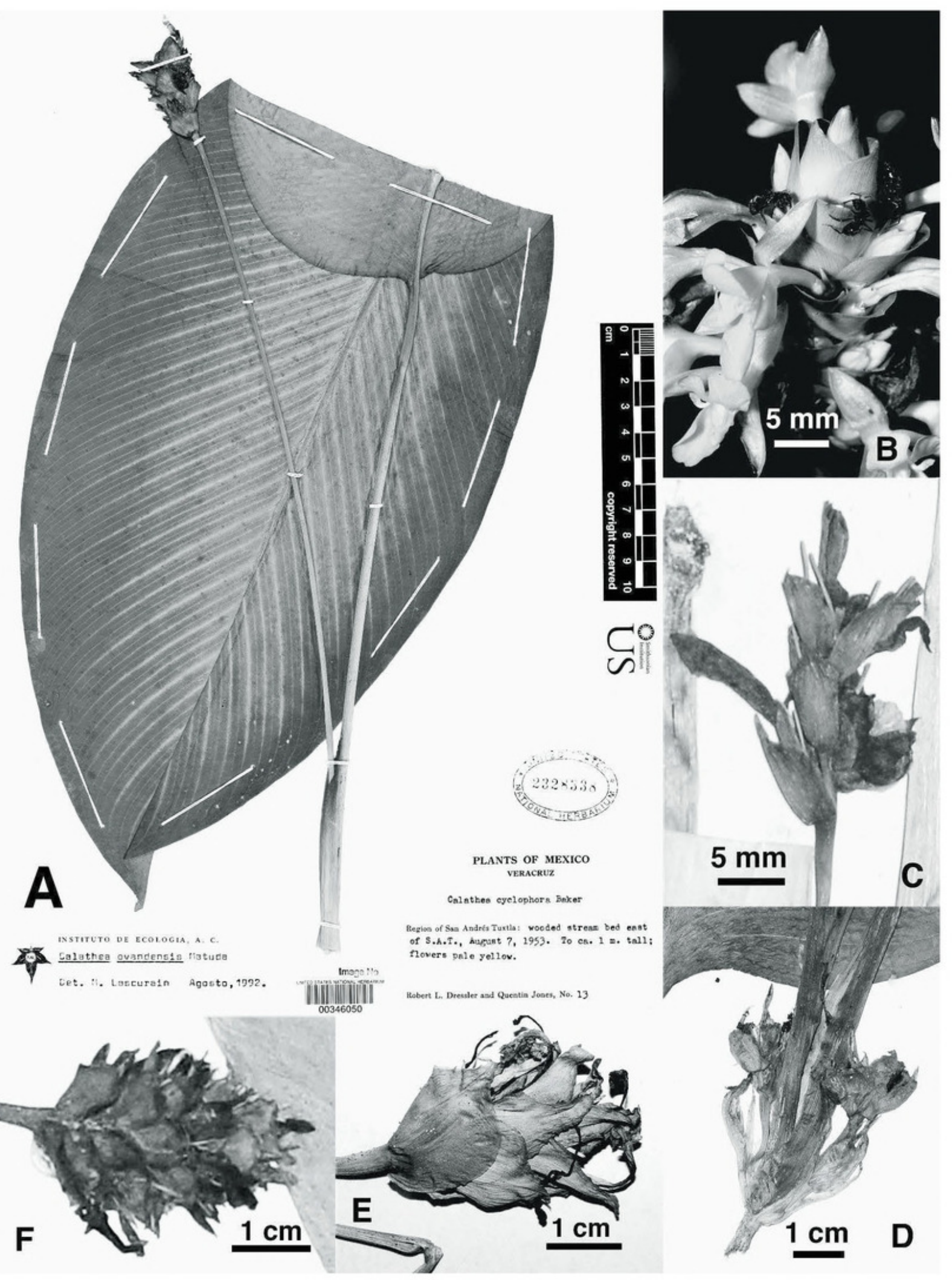

Figure 1. Comparison of inflorescences in Calathea. A, B. C. sousandradeana H. Kenn. \& Ganders. -A. Isotype. -B. Inflorescence with untripped flowers. - C. C. ovandensis Matuda. Inflorescence of holotype. D, E. C. atropurpurea Matuda. -D. Reduced basal inflorescences. - E. Inflorescence of isotype. -F. C. matudae H. Kenn. \& Ganders. Inflorescence. Photo in A provided by U.S. National Herbarium, Smithsonian Institution (Dressler \& Jones 13, US); photo in B by Carol Horvitz (Horvitz \& Cedillo T. 211, F); photo in C photographed at MEXU (Matuda 1568, MEXU); photo in D from scan provided by Kenneth Cameron, Director, University of Wisconsin Herbarium (Cevallos, Santana \& Benz 131, WIS); photo in E photographed at MEXU (Matuda et al. 31456, MEXU 8661); photo in F photographed at TEFH (Nelson \& Martínez 1729, TEFH). 


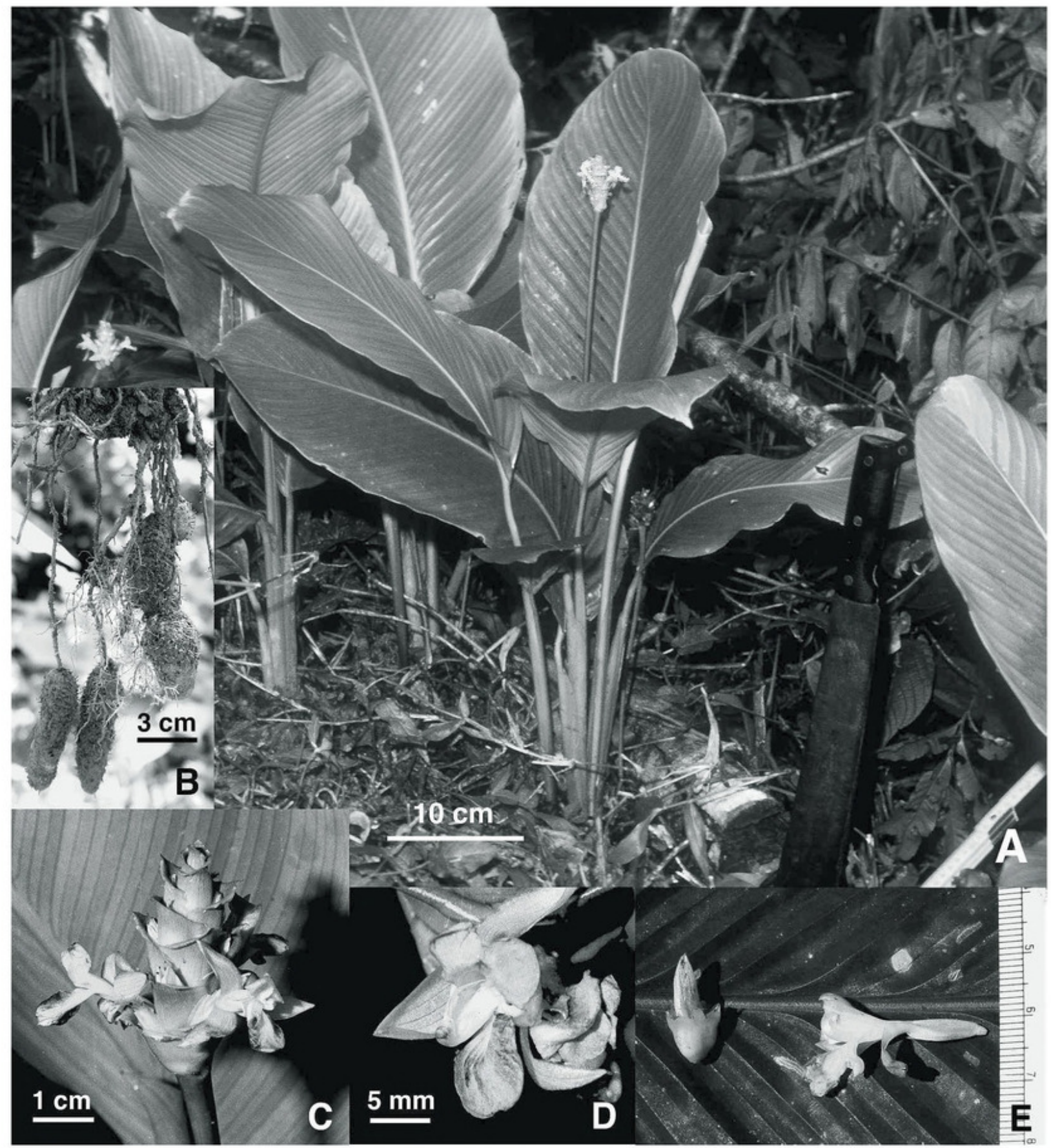

Figure 2. Calathea matudae H. Kenn. \& Ganders. - A. Habit. —B. Roots, with tuberlike swellings. —C. Inflorescence. —D. Flower untripped, face view. -E. Flower tripped, side view and capsule with persistent calyx. Photos A, C, and D of the type, Kennedy \& Breedlove 1414 (MEXU, MO, UCR); photos B and E, Kennedy \& House 6200 (DAV, EAP, UCR). Photos by the author.

isotypes, BM, BRIT, CAS, DAV, EAP, GB, MICH, MO, TEFH, TEX, UBC, UCR). Figure 2.

Haec species a Calathea atropurpurea Matuda foliorum venis tessellatis remotioribus (15 ad 20 per $5 \mathrm{~mm}$ inter venas laterales), inflorescentiis basalibus reductis absentibus atque bracteis in sicco semper brunneis superioribus acumine breviore ad apicem acuto distinguitur.

Deciduous herb, 35-95(-115) $\mathrm{cm}$ high, leafy shoots bearing 1 to 4 basal leaves and occasionally
1 cauline leaf; roots bearing subterminal, ellipsoid, starchy, tuberlike swellings; cataphylls herbaceous, narrowly ovate, obtuse, shortly apiculate, green or green tinged with purple, appressed tomentose; innermost cataphyll $8-30 \mathrm{~cm}$; stem tomentose just below node, subglabrous to glabrous basally, green or green tinged with purple, elongated internode above basal leaves, 4-27 cm. Leaves herbaceous, pleated, elliptic, $16-50.5 \times 9.8-25 \mathrm{~cm}$, apex obtuse to rounded with acumen, base unequal, broader side 
nearly rounded, narrower side broadly acute, ratio of blade widths from midrib at $3 \mathrm{~cm}$ above (distal to) junction with pulvinus 1:1.8-4.1; leaf blade grassgreen and glittering adaxially, scattered pilose, midrib olive-green, minutely tomentose; leaf surface pale gray-green abaxially, occasionally tinged with pale purple, minutely velvety tomentose, readily felt, midrib light olive-green occasionally tinged with purple, densely appressed tomentose; pulvinus olivegreen, greenish brown, or caramel-colored, tomentose throughout, (1.1-)2.3-5.6 cm; petiole dark green, often tinged with purple toward base, appressed tomentose, 0-12(-29) cm; leaf sheath not auriculate, green, darker green or tinged purple basally, appressed tomentose, more densely so along margin and apically, 16.5-35(-61) $\mathrm{cm}$. Inflorescence borne on a separate, nonleafy shoot from the rhizome or terminal on leafy shoot; additional inflorescences sometimes borne in axils of the basal leaves; inflorescences 1 per separate leafless shoot, 1 or 2(to 3 ) on leafy shoots, ovoid to ellipsoid or subcylindrical, (2.5-)4-5.5(-6.5) × (1.7-)2.3-3(-4.2) cm; peduncle green or green tinged with purple, appressed tomentose near junction with inflorescence, sparsely pilose to subglabrous basally, 24-65 cm; bracts (6 to) 10 to 32 , spirally arranged, imbricate, outer surface green, minutely appressed tomentose, inner surface green, apical recurved margin minutely tomentose, basal portion glabrous, the outermost $0.3-0.4 \mathrm{~mm}$ of margin hyaline; broadly transverse ovate in lowermost 3 or 4 bracts, basalmost bract may be retuse with central acumen, ovate to ovate-elliptic in subsequent ones, longer than wide, rounded to obtuse with an abrupt elongated acumen in lower bracts to acuminate in upper ones, outer margin and apex recurved or occasionally just the margins recurved, 1.1-2.8 $\times$ $1.2-2.4 \mathrm{~cm}$; each bract subtending 2 to 6 flower pairs; bicarinate prophyll membranous, elliptic, apex rounded, translucent faint yellowish, glabrous, 1.1-1.4 $\times$ $0.7-1.1 \mathrm{~cm}, 0.6-0.9 \mathrm{~cm}$ wide from carina to carina; secondary bract membranous, elliptic, apex rounded, translucent pale yellow, glabrous, (0.5-)0.7-0.9 cm; bracteoles 1 per flower pair, medial, indurate, claviculate, linear, light tannish yellow, 1.15-1.6 cm. Sepals membranous, obovate, acute to $90^{\circ}$, cream to white, glabrous, $10.5-13 \mathrm{~mm}$; corolla tube pale yellow to cream-colored, glabrous, $13-16 \mathrm{~mm}$; corolla lobes subequal, elliptic, apex obtuse, yellow, glabrous, ca. 12-13 mm (flower purple and white, fide Breedlove 38059, Croat 40643); outer staminode elliptic, clawed at base, yellow, lighter toward base, with or without purple streaks, ca. $10-11 \times 6-6.5 \mathrm{~mm}$; callous staminode petaloid apically, spatulate, apex bilobed, yellow or tinged purple apically, paler basally, ca. 12 $\mathrm{mm}$; cucullate staminode yellow or cream, apex likewise or tinged purple, 5-6 mm; stamen with lateral petaloid appendage, cream-white; anther cream; ovary cream to white, glabrous, $1.5-2 \times 1-1.5 \mathrm{~mm}$; style and stigma cream-colored. Capsule fleshy, obpyramidal with raised outer rim, cream to white, glabrous, $8-9 \times$ 8-9 mm, crowned by a persistent calyx; seeds usually 3 per capsule, trigonous, outer surface rugose, gray, ca. 4 $\times 4 \times 3 \mathrm{~mm}$, bearing a white aril.

Distribution and phenology. Calathea matudae occurs from Chiapas, Mexico, southeast to Olancho Department, Honduras, at mid to higher elevations from 650 to $1600 \mathrm{~m}$. According to specimen data, it was found in a fairly broad range of habitats from transitional tropical dry and deciduous forests to subtropical wet and montane rainforests. It was often noted in association with Liquidambar L. or Pinus L.Liquidambar overstories.

As would be expected with a deciduous plant, growth and flowering occur in the rainy season, from May to September, but as early as March in Honduras and as late as October in Chiapas. In flowering individuals, the inflorescence is frequently on the first shoot produced, which is usually a leafless shoot bearing only cataphylls basally. Subsequently, leafy shoots are usually produced in the axils of the cataphylls or as separate shoots from the rhizome. These leafy shoots often bear inflorescences. Occasionally, the leafy shoots may be the first to emerge and flower.

IUCN Red List category. Conservation for Calathea matudae must be considered as Least Concern (LC) according to IUCN Red List criteria (IUCN, 2001), because it is known from many localities from Chiapas, Mexico, through Guatemala to Olancho Department, Honduras, at elevations from 650 to $1600 \mathrm{~m}$.

Etymology. This species is named in honor of Eizi Matuda (1894-1978) for his many contributions to Mexican botany, especially for the Marantaceae of Chiapas.

Common names. The new species has been identified as "platanillo" and "chufle" (MacVean s.n., UVAL 74108) in Guatemala, and as "macuz" (Nelson \& Martínez 1729) and "lirio de montaña" (Molina R. 2955) in Honduras.

Discussion. Calathea matudae is distinguished by the deciduous habit; the leaf blade that is pilose adaxially and velvety tomentose abaxially; the absence of reduced basal inflorescences; the spirally arranged, tomentose green bracts with recurved margins and with the acumen acute at the tip; the claviculate bracteoles; and the yellow to cream or 
purple mottled corolla and staminodes. Calathea atropurpurea often retains a greenish color to the bracts, especially the acumen, when dried, whereas in $C$. matudae (and the second new species herein) the bracts dry brown. As in C. atropurpurea, to which C. matudae is closely related, there is variation in flower color from yellow to white or purple. In the type population, the corollas were yellow and the staminodes pale yellow streaked or tinged with purple. Flowers of other Chiapan specimens are described as white and purple, yellow and purple, or pale yellow lined with lavender. In the majority of Honduran specimens, flowers are noted as being cream or yellow, the corolla yellow, and the staminodes light yellow. However, two Molina collections from Francisco Morazán Department (Molina R. 2855, 2955 [EAP]) are described as having "flores azules" and "flores morado pallido."

Paratypes. GUATEMALA. Suchitepéquez: Agropecuaria la Corona, Chicacao, $14^{\circ} 34^{\prime} 37^{\prime \prime} \mathrm{N}, 91^{\circ} 16^{\prime} 45^{\prime \prime} \mathrm{W}, 30$ Mar. 2003, A. L. MacVean s.n. (UVAL 74108). HONDURAS. Comayagua: ca. $14 \mathrm{~km}$ E of Lago Yojoa, just outside San José de Los Planes, along Quebrada Agua Helada, $14^{\circ} 47^{\prime} \mathrm{N}, 87^{\circ} 51^{\prime} \mathrm{W}$, Mar. 1993, R. Evans 1334 (EAP, MO); region of Buenas Aires, $14^{\circ} 51^{\prime} 01^{\prime \prime} \mathrm{N}, 88^{\circ} 01^{\prime} 30^{\prime \prime} \mathrm{W}, 20$ Aug. 2006, H. Kennedy \& P. House 6200 (DAV, EAP, UCR); Desvio El Coco, ca. $3 \mathrm{~km}$ from jet. along rd. to Buenas Aires, $14^{\circ} 52^{\prime} 35^{\prime \prime} \mathrm{N}, 88^{\circ} 01^{\prime} 28^{\prime \prime} \mathrm{W}, 20$ Aug. 2006, $H$. Kennedy \& P. House 6212 (EAP, UCR); $1.5 \mathrm{~km} \mathrm{~S}$ of Las Lajas, Montaenualas Quad 444,450 E, 1639,900 N, $14^{\circ} 49^{\prime} 37^{\prime \prime} \mathrm{N}, 87^{\circ} 30^{\prime} 48^{\prime \prime} \mathrm{W}, 23$ June 1981, R. A. Meigs \& D. Lentz 1491 (TEFH, UNA); Quebrada de Barranoc de Trincheras, 13 May 1956, A. Molina R. 6971 (EAP); Montaña La Choca, Cordillera Comayagua, cerca de Coyocutena, 22 May 1956, A. Molina R. 7107 (EAP, F); Montaña La Choca en Cordillera Comayagua, cerca de Coyocutena, 14 Apr. 1957, A. Molina R. \& A. R. Molina 8121 (EAP, F, NY, US); $1 \mathrm{~km}$ al S de La Misión, sobre rocas del barranco, 20 July 1962, A. Molina R. 10937 (EAP, F, NY); Villa de Taulabé, Quebrada La Caliche, 1213 June 1976, C. Nelson et al. 3518 (EAP, TEFH); Villa de Taulabé, Quebrada La Caliche, $14^{\circ} 41^{\prime} 21^{\prime \prime} \mathrm{N}, 87^{\circ} 57^{\prime} 39^{\prime \prime} \mathrm{W}$, 21 Apr. 1978, L. Tróchez 26 (MO). Francisco Morazán: Montaña Zamquín, 14 May 1950, A. Molina R. 2855 (EAP); Montaña Zamquín, Quebrada de La Páz, 23 May 1950, A. Molina R. 2955 (EAP, F, GH, US). Olancho: Mpio. La Unión, ca. $10 \mathrm{mi}$. E of La Unión along rd. to Olanchito, ca. $15^{\circ} 03^{\prime} \mathrm{N}, 86^{\circ} 35^{\prime} \mathrm{W}, 1$ July $1994, G$. Davidse 35453 (EAP, MO, TEFH); Montaña Peña Blanca, ca. de Quebrada Catacamas, 27 Apr. 1957, A. Molina R. 8380 (EAP, F, WIS); Montaña Cara Sucia, $10 \mathrm{~km} 0$ de Campamento, 20 Sep. 1986, C. Nelson 9876 (TEFH); 8.5 km NE de Catacamas, márgines del Río Talgua (Cuevas del Talgua), 10 May 1987, A. Ortega U. 320 (MO, TEFH); Orillas del Río Real, a $8 \mathrm{~km}$ E of Catacamas, 20 May 1988, M. L. Palacios 225 (TEFH); trail betw. Catacamas \& La Presa, N of Catacamas, $14^{\circ} 50^{\prime} \mathrm{N}, 85^{\circ} 53^{\prime} \mathrm{W}, 20-25$ Mar. 1949, P. C. Standley 18699 (EAP, F); Represa Santa María del Real, 15 km al NO de Catamacas, 30 Apr. 1988, L. Velásquez 182 (TEFH). Santa Bárbara: Punta Gorda, Lago Yojoa, $14^{\circ} 53^{\prime} \mathrm{N}, 88^{\circ} 00^{\prime} \mathrm{W}, R$. Evans 1791 (EAP, HEH, MO, TEFH); Montaña Las Ventanas, Lago de Yojoa, 18 Aug.
1988, R. Zúniga 713 (TEFH). Yoro: Yoro near Pte. Grande on tributary of Río Agua (Río Pte. Grande), 22 May 1987, S. Blackmore \& M. Chorley 4065 (BM, MO); Camino de la ciudad de Yoro, a la montaña Buenos Aires, 28 Mar.-4 Apr. 1974, C. Nelson \& J. Martínez 1729 (EAP, TEFH). MEXICO. Chiapas: Mpio. Ocozocoautla de Espinosa, 18$20 \mathrm{~km}$ N of Ocozocoautla on rd. to Mal Paso, 18 Aug. 1972, D. E. Breedlove 27131 (DS, LL, MO); Mpio. Ocozocoautla de Espinosa, $32 \mathrm{~km} \mathrm{~N}$ of Ocozocoautla on rd. to Mal Paso, 6 Oct. 1974, D. E. Breedlove 38159 (DS); Mpio. Ocozocoautla de Espinosa, $22 \mathrm{~km} \mathrm{~N}$ of Ocozocoautla, 9 Oct. 1980, D. E. Breedlove \& J. Strother 45997 (CAS); Mpio. Ocozocoautla de Espinosa, $20 \mathrm{mi}$. N of Ocozocoautla along gravel rd. to Apitpac near Km 31 marker, 9 July 1977, T. B. Croat 40643 (MO); Mpio. Ocozocoautla de Espinosa, Km 18 on rd. to Malpaso from Ocozocoautla, 16 Aug. 1972, $H$. Kennedy, G. L. Webster \& S. Lynch 1489 (MEXU); Mpio. Cintalapa, NE of Cintalapa, $3 \mathrm{~km}$ E of Francisco Madero, at ridge crest, 18 Aug. 1972, D. E. Breedlove 38059 (DS, MO); Mpio. San Fernando, at rd. tunnel from Tuxtla Gutierrez to Chicoasen Dam, 9 Sep. 1976, D. E. Breedlove 40003 (DS); Mpio. San Fernando, $20 \mathrm{~km}$ NW of San Fernando beyond Colonia Cuahtemoc, 18 May 1988, D. E. Breedlove \& M. Bourell 68272 (CAS); Mpio. Berriozábal, La Vistas al N Berriozábal, 17 July 1959, D. Miranda 5397 (MEXU).

2. Calathea sousandradeana $H$. Kenn. \& Ganders, sp. nov. TYPE: Mexico. Veracruz: Mpio. San Andrés Tuxtla, region of San Andrés Tuxtla, E of San Andrés Tuxtla, wooded stream bed, 7 Aug. 1953, R. L. Dressler \& Q. Jones 13 (holotype, MEXU; isotypes, GH, MICH, NY, UC, US). Figure 1.

Haec species a Calathea atropurpurea Matuda et $C$. matudae H. Kenn. \& Ganders bracteis minoribus glabris apice margineque erectis superioribus apice obtusis rotundatisve distinguitur.

Deciduous rhizomatous herb, 36-86 cm high, bearing 1 to 3(to 6) basal leaves and 0 or 1 cauline leaf, borne above a $5.5-33 \mathrm{~cm}$ stem internode; stem green, sparsely pilose, hairs to $0.5 \mathrm{~mm}$; roots bearing subterminal, ellipsoid, starchy, tuberlike swellings; cataphylls herbaceous, narrowly ovate, apiculate, appressed tomentose, hairs sparse at very base; innermost cataphyll (8.5-)11-24.5 cm; leaf blades herbaceous, slightly pleated, ovate, occasionally elliptic, (15.2-)20-39 × (8.5-)10-19 cm, apex obtuse with acumen to abruptly acuminate, base obtuse to rounded, abruptly attenuate, somewhat unequal; leaf blade glittering deep green adaxially, scattered pilose, hairs borne on raised cushion of cells, hairs $0.25-0.3$ $\mathrm{mm}$, midrib light green, appressed tomentose medially; leaf surface light gray-green abaxially, densely velutinous, hairs $0.1-0.2 \mathrm{~mm}$, midrib appressed tomentose; pulvinus 1.4-3.1 $(-3.8) \mathrm{cm}$, olive-green, minutely tomentose throughout but occasionally tomentose adaxially, glabrous to subglabrous abaxially, hairs $0.2-0.5 \mathrm{~mm}$, longest adaxially; petiole 
green, moderately to densely tomentose, $(0-) 1.2-28.5$ $\mathrm{cm}$; leaf sheath not auriculate, $11-37.5 \mathrm{~cm}$, green, appressed tomentose, hairs readily felt, denser apically, sparse toward base. Inflorescence 1 per shoot, terminal on the leafy shoot or borne on a separate leafless shoot, often appearing before the leafy shoot develops, ovoid to ellipsoid, 2.6-4.5(-5) $\times(1.2-) 1.8-2.2(-2.5) \mathrm{cm}$; peduncle green, $28-41.5$ $\mathrm{cm}$, apicalmost $1-2 \mathrm{~cm}$ just below inflorescence glabrous, then pilose to base; bracts 11 to 19 , spirally arranged, imbricate, herbaceous, broadly transverse ovate in lower ones, ovate in uppermost bracts, apex of lowermost bract obtuse with acumen to acuminate, apex obtuse to rounded in upper ones, outer margin and apex straight, not recurved, 1-1.7(-2) $\times 0.95-$ $1.6 \mathrm{~cm}$; each bract subtending up to 6 or more flower pairs; outer surface of bracts green, glabrous; inner surface green, glabrous; bicarinate prophyll membranous, broadly ovate to subelliptic in upper bracts, apex broadly obtuse, occasionally retuse, wings extending above center back, translucent faint greenish white, glabrous, 0.9-1.2 $\times 0.6-1.1 \mathrm{~cm}$, $0.4-0.7 \mathrm{~cm}$ wide from carina to carina; secondary bract membranous, elliptic, apex shallowly emarginate, translucent faint greenish white, glabrous, 0.9$1.1 \times 0.5-0.7 \mathrm{~cm}$; bracteoles 1 per flower pair, medial, claviculate, apical portion triangular in cross section, straw-colored, 0.95-1.35 cm. Sepals herbaceous, narrowly elliptic, obtuse, pale cream-colored, glabrous, 9.5-11 $\times 2-3 \mathrm{~mm}$; corolla tube cream to light yellow, glabrous, 12-15 mm; corolla lobes subequal, elliptic, obtuse, yellow, glabrous, 8-10 $\times$ 3.5-4 mm; staminodes yellow; outer staminode elliptic, emarginate, 7-9 $\times$ ca. $6 \mathrm{~mm}$; callous staminode petaloid apically, spatulate, apex bilobed, $8-10 \times$ ca. $6 \mathrm{~mm}$; cucullate staminode $5-6 \mathrm{~mm}$; filament pale yellow, anther yellow, ca. $2 \mathrm{~mm}$; ovary smooth, cream-white, glabrous, 1.5-2 $\times 1-1.5 \mathrm{~mm}$; style and stigma yellow, back of style turning brownish after being tripped by pollinator. Capsule smooth, obpyramidal with raised rim, glabrous; crowned by a persistent calyx; seeds usually 3 per capsule, trigonous, outer surface rugose, ca. $5 \times 4.5 \times$ $4 \mathrm{~mm}$, bearing a white aril to $4 \mathrm{~mm}$ high.

Distribution, phenology, and natural history. Calathea sousandradeana is endemic to Oaxaca and Veracruz, Mexico, at low elevations from 10 to $400 \mathrm{~m}$. The most common habitats noted are tropical rainforest, tall evergreen forest, and medium semievergreen forest, mostly secondary or disturbed areas, primarily on limestone soils (suelo kárstico). In some sites, the new species is associated with Brosimum Sw., Cedrela P. Browne, Ficus L., or Bursera Jacq. ex L. Flowering is in the rainy season, from June through
October. Fruiting is concomitant with flowering throughout most of the rainy season. Capsules expand to full size in ca. 14 days after pollination (Schemske \& Horvitz, 1989: 462) and dehisce after ca. 32 days (Schemske \& Horvitz, 1988). Horvitz and Schemske (2002: 281) note that "new seeds are dormant until at least the subsequent rainy season."

Calathea sousandradeana is certainly the most comprehensively studied species of Calathea, as evidenced by the many papers cited in Horvitz and Schemske (2002), where it was called $C$. ovandensis Matuda. This species is bee pollinated, mainly by euglossine bees, but also by species of Rhathymus Lepeletier \& Serville (Schemske \& Horvitz, 1988. The claviculate bracteoles function as extrafloral nectaries and are visited by ants. The significance of these ant-plant interactions was documented by Horvitz and Schemske (1984, 1988). Immatures of the butterfly Eurybia elvina Stichel feed on buds and flowers (Horvitz et al., 1987). The seeds are ant dispersed, with the ants collecting them for the "lipid-rich aril that is used as food" (Horvitz \& Schemske, 1986: 319).

IUCN Red List category. Conservation for Calathea sousandradeana must be considered as Least Concern (LC) according to IUCN Red List criteria (IUCN, 2001), because it is known from many localities in Oaxaca and Veracruz, Mexico, at elevations from 10 to $400 \mathrm{~m}$.

Etymology. This species is named in honor of Mario Sousa S., former director of Universidad Nacional Autónoma de México herbarium (MEXU), and his wife Gloria Andrade M. for their unstinting help to innumerable visiting botanists and specifically in gratitude for their aid to my Marantaceae studies, both recently and as a graduate student.

Discussion. This species often produces an inflorescence on a leafless shoot, which may appear before a separate leafy shoot develops. This initially leafless shoot, terminating in an inflorescence, may subsequently produce leafy shoots in the axils of the cataphylls, which in turn may bear inflorescences. These inflorescences are normal and on leafy shoots, unlike the reduced basal inflorescences produced by Calathea atropurpurea.

Like Calathea atropurpurea and C. matudae, C. sousandradeana is also deciduous, with leaves pilose adaxially, green spirally arranged bracts, claviculate bracteoles, and yellow flowers. This new species differs from both $C$. atropurpurea and $C$. matudae in the generally smaller inflorescences, glabrous bracts with erect, nonrecurved margins, and the obtuse to rounded apex of the upper bracts. The flower color 
does not appear to be as variable as in C. matudae, with no mention of purple. Flower color for $C$. sousandradeana was given as yellow in all but one of the paratype collections (C. Martínez R. 1073, TEX), where it was noted as "blanca." This new species differs from $C$. atropurpurea in lacking reduced basal inflorescences. It is of geographical interest because it occupies the lowland areas in between the distributional ranges of $C$. atropurpurea and $C$. matudae.

Paratypes. MEXICO. Oaxaca: Distr. Tuxtepec, Mpio. Soyaltepec, Presa Temascal, al NO sobre la cortina de la presa, 8 Sep. 1985, L. Cortes A. \& R. Torres C. 5 (CAS, MO); lado $N$ de la cortina de Presa Temascal, 12 June 1987, $L$. Cortes A. et al. 902 (F, MO); Orilla E de la Presa de Temazcal, $100 \mathrm{~m}$ al $\mathrm{N}$ de la cortina, 23 Dec. 1986, $A$. Garcia M. et al. 2716 (RSA); Cerros Kársticos frente a las bombas de auxiliación de la Presa Miguel Alemán, Temascal, 22 Sep. 1984, R. Torres C. \& E. Cabrera 6127 (MO); Mpio. Acatlán, Cerro del Tigre, $3 \mathrm{~km}$ al Ede Acatlán via Tierra Blanca-Acatlán, 25 Aug. 1986, L. Cortes A. \& R. Torres C. 474 (F); Distr. Tuxtepec, Tuxtepec to Oaxaca, 5 $\mathrm{km} \mathrm{S}$ of Tuxtepec, 26 Sep. 1986, B. Hammel \& M. Merello 15460 (MO); Distr. Juchitán, Mpio. Matías Romero, Los Angeles $20 \mathrm{~km}$ al NO del entronque con la carr. Matías Romero-Acayucan, la entrada se encuentra adelante de Martía Dehesa, 23 Oct. 1987, C. Martínez R. 1073 (TEX); Mogoñe (on Ferro Caril N.T.), 9 June 1910, C. R. Orcutt 5225 (DS, MO); Cerro de Sebastopol, near Fabrica Papel, ca. $8.5 \mathrm{mi}$. by rd. SW from Tuxtepec, ca. $18^{\circ} 05^{\prime} \mathrm{N}$, 96 $08^{\prime}$ W, 21 June 1969, G. L. Webster \& G. Breckon 15404 (DAV). Veracruz: Mpio. San Andrés Tuxtla, about $5 \mathrm{~km}$ al NE de San Andrés Tuxtla, Laguna Encantada, 28 June 1972, J. H. Beaman 6299 (TEX, UCR, XAL); Catemaco, 1953, H. Bravo 31 (MEXU); Laguna Escondida, 23 Nov. 1969, G. M. Calderon 2107 (GH); 8 km al N de San Andrés Tuxtla, Laguna Encantada, $18^{\circ} 31^{\prime} \mathrm{N}, 9^{\circ} 09^{\prime} \mathrm{W}, 23$ Sep. 1974, J. I. Calzada 1512 (MO, NY); $8 \mathrm{~km}$ al N de San Andrés Tuxtla, Laguna Encantada, $18^{\circ} 28^{\prime} \mathrm{N}, 95^{\circ} 10^{\prime} \mathrm{W}, 4$ Sep. 1981, J. I. Calzada 8098 (MEXU, XAL); 1 km al N de San Andrés Tuxtla, Laguna Encantada, 9 Aug. 1983, $R$. Cedillo T. 2430 (MEXU, MO, TEX); $3 \mathrm{~km} \mathrm{NE} \mathrm{of} \mathrm{San}$ Andrés Tuxtla, on rim \& steep slopes around a lake-filled volcanic crater, $18^{\circ} 27^{\prime} 30^{\prime \prime} \mathrm{N}, 95^{\circ} 11^{\prime} 15^{\prime \prime} \mathrm{W}, 2$ July $1982, M$. Nee et al. 24757 (BRIT, MO, NY, XAL); Mpio. Hueyapan de Ocampo, Los Mangos, ca. $22^{\circ} 13^{\prime} \mathrm{N}, 97^{\circ} 49^{\prime} \mathrm{W}, 12$ Sep. 1972, R. Cedillo T. \& J. I. Caldada 28 (MEXU, UCR); Los Chorros, cerca del camino San Andrés Tuxtla y Cerro Amarillo, 8 Sep. 1977, C. Horvitz \& R. Cedillo T. 211 (F, NY). State Unknown: Novae Hispaniae, 1787-1795-1804, Sessé et al. 87 (F 846441, as "Amomum").

Acknowledgments. I am especially grateful to Andrew Sanders of the UCR herbarium for allowing me the space to store and study all the Mesoamerican loan material and for his taxonomic discussions and insight. I'm very grateful to Mario Sousa and Gloria Andrade (MEXU) for their invaluable assistance to me in the herbarium and in providing transport, which allowed many more hours of herbarium study. I thank the following for help and use of the herbarium facilities: G. Davidse (MO), C. Niezgoda (F), G. Salizar (MEXU), E. Pöll (UVAL), M. Véliz and J. Vargas (BIGU), and M. Storek Cermakova (USCG). Thanks to G. Pilz for arranging housing and use of EAP facilities; Z. Avila for housing, herbarium use, and field transport (HEH); and P. House for transport in Honduras. C. Niezgoda provided accommodations and transport for my stay at F, and T. Salvato provided such at UCR. Thanks to C. Horvitz for loan of photos of and discussions about the Veracruz species. I thank the curators of BRIT, CAS, DAV, DH, DUKE, F, MEXU, MICH, MO, NY, TEX, WIS, $\mathrm{UC}$, and US for loan of their specimens.

\section{Literature Cited}

Horvitz, C. C. \& D. W. Schemske. 1984. Effects of ants and an ant-tended herbivore on seed production of a neotropical herb. Ecology 65: 1369-1378.

Horvitz, C. C. \& D. W. Schemske. 1986. Seed dispersal of a neotropical myrmecochore: Variation in removal rates and dispersal distance. Biotropica 18: 319-323.

Horvitz, C. C. \& D. W. Schemske. 1988. A test of the pollinator limitation hypothesis for a neotropical herb. Ecology 69: 200-206.

Horvitz, C. C. \& D. W. Schemske. 2002. Effects of plant size, leaf herbivory, local competition and fruit production on survival, growth and future reproduction of a neotropical herb. J. Ecol. 69: 200-206.

Horvitz, C. C., C. Turnbull \& D. J. Harvey. 1987. Biology of immature Eurybia elvina (Lepidoptera: Riodinidae), a myrmecophilous metalmark butterfly. Ann. Entom. Soc. Amer. 80: 513-519.

IUCN. 2001. IUCN Red List Categories and Criteria, Version 3.1. Prepared by the IUCN Species and Survival Commission. IUCN, Gland, Switzerland, and Cambridge, United Kingdom.

Lascurain, M. 1995. Marantaceae. Fasc. 89, pp. 1-39 in V. Sosa (editor), Flora de Veracruz. Instituto de Ecologia, A.C., Xalapa, Veracruz and University of California, Riverside.

Lascurain, M. 1996. A new species of Calathea (Marantaceae) from Veracruz, Mexico. Novon 6: 385-386.

Matuda, E. 1950. Estudio de las plantas de Chiapas VIII. Marantaceas de Chiapas. Anal. Inst. Biol. Méx. 21: 319 343.

Matuda, E. 1956. Marantaceas in plantas nuevas y interesantes de Mexico. Anal. Inst. Biol. Méx. 27: 359360.

McVaugh, R. 1989. Marantaceae. Pp. 99-109 in W. R. Anderson (editor), Flora Novo-Galiciana, Vol. 15. University of Michigan Herbarium, Ann Arbor.

Schemske, D. W. \& C. C. Horvitz. 1988. Plant-animal interactions and fruit production in a neotropical herb: A path analysis. Ecology 69: 1128-1137.

Schemske, D. W. \& C. C. Horvitz. 1989. Temporal variation on a floral character. Evolution 43: 461-465.

Standley, P. C. \& J. A. Steyermark. 1944. Studies of Central American Plants IV. Field Mus. Nat. Hist. Bot. Ser. 23: 31-109. 


\section{$2 \mathrm{BHL}$ Biodiversity Heritage Library}

Kennedy, Helen and Ganders, Fred R . 2011. "Calathea matudae and C. sousandradeana, New Species of Marantaceae from Mexico and Northern Central America." Novon a journal of botanical nomenclature from the Missouri Botanical Garden 21(1), 58-65. https://doi.org/10.3417/2009042.

View This Item Online: https://www.biodiversitylibrary.org/item/180102

DOI: https://doi.org/10.3417/2009042

Permalink: https://www.biodiversitylibrary.org/partpdf/218456

\section{Holding Institution}

Missouri Botanical Garden, Peter H. Raven Library

\section{Sponsored by}

Missouri Botanical Garden

\section{Copyright \& Reuse}

Copyright Status: Permission to digitize granted by rights holder

Rights: https://www.biodiversitylibrary.org/permissions

This document was created from content at the Biodiversity Heritage Library, the world's largest open access digital library for biodiversity literature and archives. Visit BHL at https://www.biodiversitylibrary.org. 